одне $з$ найяскравіших і найглибших досліджень одного із творів киянина, авангардиста Казимира Малевича.

\title{
Література:
}

1. Горбачов Дмитро. Перший (Київський) «Жіночий торс» Малевича з серії «Форма і колір». Рукопис. С. 1-14.

2. Горбачов Д., Мельник В. Український авангард // Пам'ятки України - 1991- № 90.

3. Гренберг Ю., Писарева С. Масляные краски XX века и експертиза произведений живописи. Планета Музыки. Москва. 2017.

4. Казимир Северинович Малевич «Форма, колір і відчуття». «Сучасна архітектура», 1928, № 5, С. 157-159.

5. К.С. Малевич, «Архітектура, станковий живопис, скульптура» [1929], в кн. Казимир Малевич. Київський период 1928-1930 (склала Тетьяна Філевська), Київ, Родовід, 2016, с. 127.

6. Малевич К. З автобіографії // Україна. - 1988. - № 29.

7. Малевич К. Архітектура, станкове малярство та скульптура // Авангард-альманах пролетарських митців «Нова генерація» - К., 1930. - № B.

8. Методика дослідження рукописних записів і підписів, виконаних на незвичному матеріалі письма незвичними пишучими приладами (р/код 1.1.55). - Харків, 2012.

9. Маркаде Ж.-К. «Жіночий торс № 1» Малевича. Рукопис, с. 8-9.

10. «Нова генерація» (Харків, № 6-9,1930).

11. Судебно-почерковедческая експертиза. - М., 1971. - ч. 1, 2.

DOI https://doi.org/10.30525/978-9934-26-004-9-49

\section{ТЕНДЕНЦІЇ РОЗВИТКУ СУЧАСНОЇ УКРАЇНСЬКОЇ КЕРАМІКИ}

\section{Кулініч Л. О.}

стариий викладач кафедри образотворчого мистецттва та дизайну Центральноукраїнського державного педагогічного університету імені Володимира Винниченка м. Кропивницький, Україна

Сучасна художня кераміка - яскраве явище в українському мистецтві. Поява і становлення професійної художньої кераміки пов'язане 3 процесами, що відбувалися в культурно-мистецькому середовищі другої половини XX століття. До середини XX століття завданням професійної кераміки вважалося вивчення і інтерпретація надбань традиційного 
народного мистецтва. В 1960-х роках наявними стали тенденції розмежування новаторського і традиційного підходів на рівні образного мислення. Вже у 1970-х - 1980-х роках художники представляли значну кількість творчих підходів у застосуванні керамічних матеріалів та виражальних засобів, численні індивідуальні модифікації традиційних для кераміки, та запозичених в інших сферах творчості, художніх прийомів. Згодом, в умовах більшої творчої свободи, перед художниками відкривається постмодерністичний світ 3 усім його розмаїттям творчих підходів, форм, засобів вираження. Проте, разом 3 тим, занепадає матеріально-технічна база художньої кераміки. Та вже на початку XXI століття, нове покоління українських керамістів знаходить можливості реалізації в кераміці актуальних тенденцій розвитку сучасного мистецтва, сягас нових творчих здобутків та визнання на міжнародному рівні $[1$, с. 3-8]. Як зауважує Зоя Чегусова, сучасна професійна кераміка, відмежувавшись від вжиткової функції, впевнено стверджує «свою естетичну незалежність, самодостатність, самоцінність, доводячи, що вона, подібно до образотворчих видів, так само здатна на «творення образів», які мають існувати у формах декоративної пластики, арт-об'єктів, настінних панно і в інтер'єрному середовищі, i у виставковому просторі, і в музеях...» [5]. Проте, термінологічна, хронологічна неоднозначність та невизначеність, а також накладання низки нових термінів на пострадянську класифікацію мистецтв, значною мірою ускладнює участь художників-керамістів у сучасних мистецьких процесах, які давно вже перестали бути «прикладними» $[1,2] .3$ огляду на це, важливого значення набуває, започаткування Олесею ДворакГалік фестивалю сучасної кераміки «ЦеГлина» та виставкових проектів «Сучасне «мистецтво вогню» України (кераміка, скло, метал)» (автор концепції i куратор-координатор - Зоя Чегусова), що створило можливість демонструвати творчі здобутки художників-керамістів та популяризувати сучасну професійну художню кераміку. Таким чином, стало очевидним, що сучасна авторська кераміка відповідає запитам практично всіх напрямків сучасного мистецтва, і реалізується у різних формах його втілення, таких як: арт-об'єкти, арт-дизайн, інсталяція, станкова та станково-декоративна кераміка, концептуальний дизайн. Отже, творче експериментування українських митців розгортається у сфері концептуальної кераміки. Саме вона займає важливе місце в мистецтві XXI століття, як наступний етап сучасного мистецтва кераміки. Проте, новостворений мистецький простір виявив і те, що об'єднавшись, художники зрозуміли свою потребу «рухатися в різних напрямках. Відмежувався посуд і ужиткова кераміка, яка знову набула 
популярності, бо люди повертаються до використання керамічного посуду у побуті» [2]. Тобто утилітарно функціональна художня кераміка розвивається паралельно зі станковою, але сьогодні вона вже є образно, стилістично оновленою та збагаченою новими кольорово-графічними та технологічними прийомами. 3 цього приводу, Зоя Чегусова зауважує, що коли «твір виконує естетичну функцію на рівні витвору високого мистецтва, і водночас має вжиткове призначення - це найвищий мистецький пілотаж...» [5].

Тематично-образна спрямованість творів сучасної станководекоративної професійної кераміки надзвичайно широка. Художники, засобами образно-пластичного i колірного вирішення відтворюють трагізм і напругу подій в Україні в останні роки (Г. Міміношвілі, Н. Попова, М. Бережненко); піднімають актуальні для сьогодення проблеми екології (О. Пильник, М. Кузьменко); розмірковують про філософію людського життя, використовуючи для візуалізації символічні зображення та відомі знакові форми (П. Печорний, О. Дворак-Галік, Ю. Мусатов); образно переосмислюють орнаментальні традиції трипільської культури та давніх слов'ян (О. Чепурна, М. Росул, В. Віньковський); звертаються до трансформацій та інтерпретацій природних явищ і мотивів, що втілюючись у складні за конфігурацією декоративні об'єми, викликають різноманітні асоціації (Г. Друль, А. Симкович, Ю. Жарікова); наділяють особливим змістом, знаходять надзвичайне у звичайних предметах (С. Гібаленко); а також ліричнодекоративні образи (М. Вахняк) та зооморфна пластика 3 яскравим розписом (Н. Ісупова) [3].

Формально-стилістичні пошуки художників також багатовекторні та розмаїті. Більшість художників у своїх керамічних пошуках тяжіє до фігуративної чи абстрактної пластики. В межах однієї експозиції можуть співіснувати абстрактно-декоративні i образотворчі, відстороненобезсюжетні і філософсько-змістовні твори, в яких митці, кожний посвоєму, втілюють розуміння світу в часових і просторових вимірах [5]. Все частіше у виставковому просторі можна бачити керамічні арт-об'єкти та інсталяції, які передбачають трансформації - зміни розташування елементів композиції, що $є$ засобом реалізації авторської ідеї. Такі композиції вирізняються неоднозначністю сприймання та багатоваріантністю (В. Хижинський, О. Дворак-Галік, Н. Попова, О. Пильник, Г. Міміношвілі, Т. Павлишин-Святун). В кераміці, як і в скульптурі, знайшли своє місце своєрідні об'єкти - кінетичні конструкції, що являють собою динамічні системи, які мають відносно незалежні рухомі елементи, 
певним чином поєднані. Можливість взаємодії глядачів 3 такими кінетичними скульптурами - також одна з сучасних тенденцій.

Українські художники керамісти, у реалізації своїх творчих задумів, виявляють досконалі знання технічних прийомів, тонке відчуття специфіки матеріалу, прагнення до технологічних експериментів. Художники поєднують різні керамічні маси та різні способи випалу, що урізноманітнює та збагачує фактури тощо. Широко використовують виражальні можливості кольору. Часто віртуозно, мінімальними засобами досягають максимальної виразності, зберігаючи при цьому специфічні властивості матеріалу. Саме активне спрямування до новітніх образно-пластичних та технічних експериментів, i водночас, прихильність до збереження найкращих національних мистецьких традицій, виділяє Зоя Чегусова, як найважливішу особливість сучасного професійного декоративного мистецтва України в цілому, і художньої кераміки, зокрема [4].

Отже, сучасна професійна кераміка, різноманітна за жанрами, тематикою творів, засобами художнього вираження, виявляє зв'язок, наступність, діалог між традицією та сучасністю, зміцнює свої позиції в Україні і гідно представлятиме творчість українських художниківкерамістів на міжнародному рівні.

\section{Література:}

1. Голубець О., Дворак-Галік О., Хижинський В. Сучасна українська кераміка. Львів, 2018. 136 с.

2. Корусь О. Олеся Дворак-Галік: «Ми працюємо, щоб представляти столиці мистецтво керамістів». URL: http://artukraine.fitel.io/a/olesyadvorak-galik--mi-pracyuyemo-shchob-predstavlyati-stolici-mistectvokeramistiv/\#.XqV2Jj9n0y5

3. Хижинський В. «ЦеГлина-2018»: час трансформацій. URL: https://chernozem.info/journal/ceglina-2018-chas-transformaciy/

4. Чегусова 3. «Емансиповане» мистецтво, народжене творчим вогнем. URL: http://artukraine.fitel.io/a/emansipovane-mistectvo-narodzhenetvorchim-vognem1--1/

5. Чегусова 3. «ЦеГлина»: емансипація кераміки від традиційної вжиткової функції. URL: http://artukraine.fitel.io/a/ceglina--emansipaciyakeramiki-vid-tradiciynoi-vzhitkovoi-funkcii/ 